\title{
1. Wrap contracting and the online environment: Causes and cures
}

\author{
Nancy S. Kim
}

\section{INTRODUCTION}

Online contracts are ubiquitous. Users must agree to them in order to join social networking sites, purchase products, download music, and check email. Companies may present online contracts in a variety of ways. They may present the terms in a scroll box, behind a hyperlink, on several pages, or all on one page. They may require users to click on an "Accept" icon to show agreement, or they may simply assume that continued use constitutes acceptance. Now, barely twenty years after the Internet became widely accessible to the average person, nearly every website imposes some type of contract on its visitors. Although contract terms are ubiquitous online, most consumers fail to read or even notice them. Yet, despite the failure of consumers to recognize or even read online terms, courts and companies continue to treat them as binding contracts.

The early Internet contracting cases involved users who attempted to exploit the vulnerabilities of code and digital content. Software companies, believing that copyright was ineffective to stop certain types of unauthorized copying, attempted to prevent and prohibit it through contract. They developed new contracting forms- "wrap contracts" 1 - which users accepted through actions such as clicking on an "Accept" icon or tearing off product packaging. Although these novel contracting forms defied traditional contract law rules, courts enforced them in order to prevent bad actors from engaging in unfair business practices that would have hindered the growth of fledgling software and Internet companies.

This chapter explores the origins of online contracts and the development of the law in this area. It explains how contract law has ended up in a realm where judicially constructed notions of reasonableness clash against reality and traditional doctrinal rules are twisted in a way that favors drafters over adherents. Finally, this chapter proposes how contract law might be applied in a way that better reflects the reasonable expectations and intent of both parties.

1 Elsewhere, I have defined "wrap contracts" as "a blanket term to refer to a unilaterally imposed set of terms which the drafter purports to be legally binding and which is presented to the nondrafting party in a nontraditional format." NANCY S. KIM, WRAP CONTRACTS: FOUNDATIONS AND RAMIFICATIONS 2 (2013). For purposes of this chapter, I use the term to refer specifically to shrinkwrap, clickwrap, and browsewrap forms, which are discussed further in Part II. 


\section{Research handbook on electronic commerce law}

\section{THE EMERGENCE OF ONLINE CONTRACTS}

Online contracts are a species of the standard form agreements that govern many consumer transactions. The advantages and disadvantages relating to standard form contracts generally have been thoroughly discussed by other contract law scholars. ${ }^{2}$ The primary advantage of adhesive standard form contracts is that they streamline and facilitate transactions, and reduce costs for drafting companies, with the savings then, supposedly, passed on to the consumer. ${ }^{3}$ The primary disadvantages of adhesive standard form contracts are that they are one-sided in favor of businesses, lack meaningful consent, subvert contract doctrine, and degrade important rights. ${ }^{4}$

While online contracts share similarities with paper adhesive form contracts, there are important differences resulting from differences in their form. Users may perceive a mouse click differently from signing a paper document. ${ }^{5}$ The weightlessness of digital terms and the ability to hyperlink pages permit drafters to impose lengthier contracts without the incremental cost that paper would impose. The contracting environment online also differs from that offline. The online environment may be a less-than-ideal setting for contracting. Consumers, eager to buy shoes or comment on a friend's latest post, are not expecting to be blindsided by a contract and may not be in the frame of mind needed to dissect complex legal language. The visually stimulating online environment may distract users from focusing on dense legalese. Furthermore, the norm of impulsivity that seems to control online interactions may encourage clicking "accept" but discourage reading.

The growth of the Internet and the proliferation of websites brought a concomitant growth in digital contracts. Many websites contain digital terms which are hyperlinked across multiple pages. The sheer volume of digital terms encountered online by the average person is staggering, which makes it highly impracticable for anyone to read them. ${ }^{6}$ Aggravating this accumulation of terms, digital contracts are easier to change

2 See, e.g., Friedrich Kessler, Contracts of Adhesion-Some Thoughts about Freedom of Contract, 43 Colum. L. Rev. 629 (1943); Arthur A. Leff, Contract as Thing, 19 Am. U. L. ReV. 131 (1970); Russell Korobkin, Bounded Rationality, Standard Form Contracts, and Unconscionability, 70 U. Chi. L. Rev. 1203 (2003); MARgaret JANE Radin, Boilerplate: The Fine Print, VANISHING Rights, AND THE RULE OF LAW (2013); Todd Rakoff, Contracts of Adhesion: An Essay in Reconstruction, 96 HaRV. L. REV. 1173 (1983); W. David Slawson, Standard Form Contracts and Democratic Control of Lawmaking Power, 84 HARV. L. REV. 529 (1971).

3 Kessler, supra note 2, at 632 (stating that "society as a whole ultimately benefits from the use of standard contracts" if the reduction of costs is reflected in reduced prices). There is little data to support the assumption that these savings are passed along to consumers. See RADIN, supra note 2, at 290-91, n.21 (noting that the argument that cost savings from using standard form adhesive contracts are passed on to consumers is not validated in practice and demonstrates a "breathtaking coup of armchair economics").

4 See generally RADIN, supra note 2.

5 For a discussion of the signaling role of contracts and in particular, online contracts, see Juliet M. Moringiello, Signals, Assent and Internet Contracting, 57 RUTGERS L. REV. 1307 (2005).

6 See, e.g., James Gibson, Vertical Boilerplate, 70 WASH. \& LEE L. REV. 161, 190 (2013) (noting that the "average" computer purchase binds the consumer to twenty-five contracts). 
than paper ones and many contain provisions that allow the drafter to modify the terms at any time.

The online contracting environment and the abundance of online contracts exacerbate cognitive biases that hinder optimal decision-making and permit drafter opportunism. The proliferation of online contracts makes it difficult for consumers to differentiate significant legal undertakings from those which are trivial.

While the date of the initial appearance of wrap contracts is uncertain and likely unverifiable, scholars generally agree that their use was tied to the business needs of software companies. ${ }^{7}$ Computers and the software to operate them, formerly found primarily in a business or university setting, became a mass market consumer product. In a lengthy footnote, the Third Circuit in Step-Saver Data Systems v. Wyse Technology explained the reasons that software companies licensed rather than sold software:

When these form licenses were first developed for software, it was, in large part, to avoid the federal copyright law first sale doctrine ... Under this doctrine, one could purchase a copy of a computer program, and then lease it or lend it to another without infringing the copyright on the program. Because of the ease of copying software, software producers were justifiably concerned that companies would spring up that would purchase copies of various programs and then lease those to consumers ... By characterizing the original transaction between the software producer and the software rental company as a license, rather than a sale, and by making the license personal and non-transferable, software producers hoped to avoid the reach of the first sale doctrine and to establish a basis in state contract law for suing the software rental companies directly. ${ }^{8}$

The uncertainty surrounding whether software was protected by copyright laws ${ }^{9}$ and the impracticability of individually negotiating licenses prompted companies to take matters into their own hands and attempt to protect through contract what otherwise might be vulnerable to competitors.

7 See Thomas M.S. Hemnes, Restraints on Alienation, Equitable Servitudes, and the Feudal Nature of Computer Software Licensing, 71 DENV. U. L. REV. 577, 578 (1994) (explaining how lawyers for software developers, uncertain whether patent or copyright law protected software, believed that trade secret law alone could protect their clients and so proposed software licenses as a way to create a nondisclosure obligation that would not be a restraint on alienation). For a more general discussion of how licenses developed to control software use, see Douglas E. Phillips, The Software License Unveiled: How Legislation By LiCENSE CONTROLS SOFTWARE ACCESS 3-51 (2009).

8 Step-Saver Data Sys., Inc. v. Wyse Tech., 939 F.2d 91, 108 n.7 (3d Cir. 1991).

9 See Mark A. Lemley, Intellectual Property and Shrinkwrap Licenses, 68 S. CALIF. L. REV. 1239, 1242-43 (1995); Michael J. Madison, Reconstructing the Software License, 35 LoY. U. CHI. L.J. 275, 313-14 (2003); see also Nancy S. Kim, The Software Licensing Dilemma, 2008 BYU L. REV. 1103, 1110-12 (discussing the issues faced by software companies in "selling" their product to consumers). 


\section{Research handbook on electronic commerce law}

\section{A. Shrinkwrap Agreements}

Companies sought to license software with minimal fuss by inserting contract terms into the package containing the software. ${ }^{10}$ These terms became known as "shrinkwrap" licenses. ${ }^{11}$ Early cases found these end user license agreements unenforceable, although the rationales of these cases differed. In Vault Corp. v. Quaid Software, Ltd., the Fifth Circuit stated that a license agreement that accompanied the software was unenforceable as it was preempted by federal copyright law. ${ }^{12}$ In another case, Step-Saver Data Systems v. Wyse Technology, the Third Circuit held that the contract was formed when the software was purchased. ${ }^{13}$ Accordingly, the "box-top" license terms were merely "proposals for modification" under Uniform Commercial Code ("UCC") § 2-207 and were not part of the transaction as the consumer had not assented to them.

The law surrounding shrinkwraps shifted and solidified with two cases, both decided by the Seventh Circuit. In ProCD v. Zeidenberg, the plaintiff, ProCD, had compiled telephone directories into a database which it sold on compact discs, offering a lower price to consumers for "personal use" than it did to manufacturers and retailers. ${ }^{14}$ The company sought adherence to its price discrimination policy through a license which was contained in the user's manual. The license terms were not accessible until after purchase, but the outside of each package stated that the software was subject to enclosed terms. The defendant, Matthew Zeidenberg, purchased a "personal use" version of the software and then sought to resell the information for a lower price than ProCD's commercial use price. Zeidenberg argued that ProCD made an offer which he accepted by purchasing the software. ${ }^{15}$ The Seventh Circuit, however, found that the purchase of the software did not complete contract formation. Instead, the court quoted UCC $\S 2$-204(1) for the proposition that a contract for the sale of goods may be made "in any manner sufficient to show agreement, including conduct by both parties which recognizes the existence of such a contract." 16 According to the court, ProCD proposed a contract that Zeidenberg accepted when he did not return the software after "an opportunity to read the license at leisure." 17 The court found further support for its rationale in UCC $\$ 2-606$, which provides that a buyer has accepted goods when "after

10 See Robert L. Oakley, Fairness in Electronic Contracting: Minimum Standards for Non-Negotiated Contracts, 42 Hous. L. REV. 1041, 1048-49 (2005) (noting that as computers became a "consumer commodity" it was "no longer possible to have a negotiated contract" and given the "considerable uncertainty at the time about the scope of copyright protection for software" companies turned to shrinkwrap licenses).

11 A shrinkwrap license is contained within product packaging, but typically a notice of the existence of terms is visible outside the packaging. It is usually wrapped in plastic wrap with the product or otherwise packaged with the product in such a way that customer contact is unavoidable. See Register.com, Inc. v. Verio, Inc., 356 F.3d 393, 428 (2d Cir. 2004).

12 Vault Corp. v. Quaid Software, Ltd., 847 F.2d 255, 270 (5th Cir. 1988).

13 Step-Saver Data Sys., Inc. v. Wyse Tech., 939 F.2d 91 (3d Cir. 1991).

14 ProCD, Inc., v. Zeidenberg, 86 F.3d 1447, 1449 (7th Cir. 1996).

15 Id. at 1450.

16 Id. at 1452.

17 Id. 
an opportunity to inspect, he fails to make an effective rejection under $§ 2-602(1)$.'” 18 The court distinguished Step-Saver as a "battle-of-the-forms" case which was inapplicable because the case before it involved only one form. ${ }^{19}$

Another case decided by the Seventh Circuit the following year, Hill v. Gateway 2000, made plain that the reasoning in ProCD was not limited to software transactions but applied to the "law of contract."20 Although that case did not involve a shrinkwrap, it extended ProCD's rationale to all "rolling contracts" where terms follow, rather than precede, the transaction they purport to govern. ${ }^{21}$ In Hill v. Gateway, the Hills ordered a computer from Gateway over the telephone. The computer arrived in a box containing a list of terms that purported to be binding on the Hills unless they returned the computer within thirty days. The couple kept the computer for more than thirty days before complaining about the way it worked. They also claimed that they did not receive adequate notice of the arbitration clause. The court rejected their claim, stating the terms "stand or fall together." 22 It adopted ProCD's construction of the UCC that would bind a consumer to terms received after a transaction provided there was an opportunity to review and reject them.

Both opinions were written by Judge Frank Easterbrook, who focused on the economic benefits of using the rolling contract form and its practical advantages in streamlining and facilitating transactions. In Hill v. Gateway, the court reasoned that "[p]ractical considerations support allowing vendors to enclose full legal terms with their products." ${ }^{23}$ In ProCD v. Zeidenberg, the court recognized the vulnerabilities of software and the risks that unauthorized copying posed to software companies and consumers. ProCD had spent over $\$ 10$ million compiling the directory of phone listings which Zeidenberg then sought to resell. ${ }^{24}$ Easterbrook's analysis in both cases rejected the traditional rules of offer and acceptance and espoused a view that facilitated the imposition of standard terms to govern commercial transactions. Under this approach, the onus is on the purchaser to actively reject the terms after a reasonable opportunity to review them. Under traditional contract law, however, silence does not constitute acceptance unless the offeree so intends. ${ }^{25}$

Although many courts have followed the rationale in ProCD v. Zeidenberg with regard to terms that follow a transaction, others have resisted. For example, in SoftMan Products Co. v. Adobe Systems, the federal district court for the Central District of California held that the terms of an end user license agreement ("EULA") were unenforceable. In that case, SoftMan Products Company ("SoftMan") unbundled Adobe "Collection" software and sold individual components as standalone products. ${ }^{26}$ Adobe alleged that unbundling and selling the software in this manner violated the terms of its

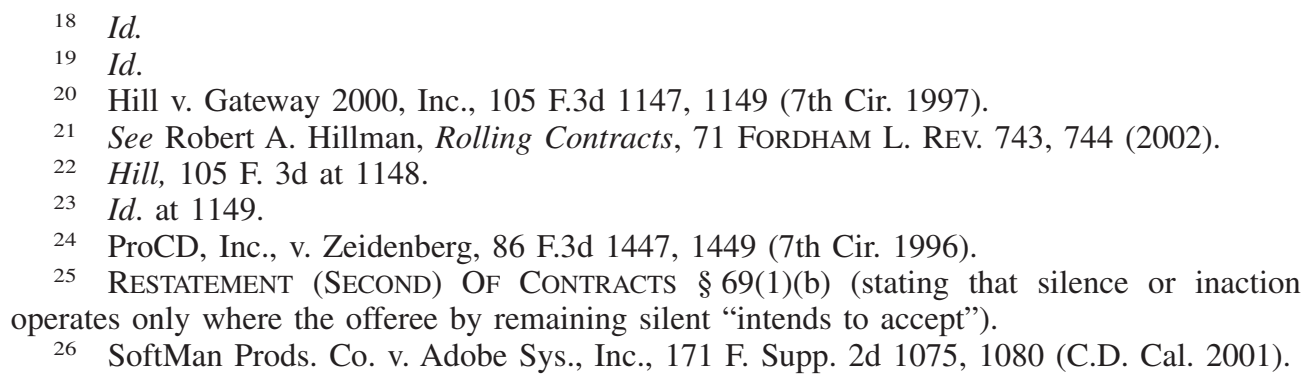


license agreements and infringed its copyright. Each Collection product was accompanied by a EULA to which the customer had to agree when it installed the software (presumably, this would be a "rolling clickwrap" agreement). The terms of the EULA prohibited the individual distribution of software; however, it was undisputed that SoftMan did not install the software that it sold. Adobe argued that because the boxes containing the Adobe software clearly indicated on the outside that use was subject to the EULA, the EULA was enforceable against SoftMan. The court disagreed:

[T] he existence of this notice on the box cannot bind SoftMan. Reading a notice on a box is not equivalent to the degree of assent that occurs when the software is loaded onto the computer and the consumer is asked to agree to the terms of the license. ${ }^{27}$

The court noted that the validity of shrinkwrap licenses was a "much-disputed question" 28 but declined to resolve the issue because it found that SoftMan had not assented to the terms of the EULA.

In Klocek v. Gateway, Inc., Gateway argued that the plaintiff consumer was required to arbitrate claims under Gateway's Standard Terms and Conditions Agreement, a copy of which was included in a box with its product. ${ }^{29}$ The court disagreed:

The Court is not persuaded that Kansas or Missouri courts would follow the Seventh Circuit reasoning in Hill and ProCD. In each case the Seventh Circuit concluded without support that UCC § 2-207 was irrelevant because the cases involved only one written form. ... This conclusion is not supported by the statute or by Kansas or Missouri law. ${ }^{30}$

The Klocek court further noted that in "typical consumer transactions, the purchaser is the offeror, and the vendor is the offeree." 31 Accordingly, it assumed that the plaintiff consumer made the offer to purchase the computer and that Gateway accepted the offer by completing the sales transaction or agreeing to ship and/or shipping the computer. ${ }^{32}$ Under UCC $\$ 2-207$, the additional or different terms in the Standard Terms and Conditions Agreement did not become part of the agreement between the parties unless the plaintiff expressly agreed to them. ${ }^{33}$ In a footnote, the court acknowledged the "practical considerations" involved in commercial transactions but stated that it was "not unreasonable" to expect a vendor to "clearly communicate" the terms at the time of sale. ${ }^{34}$

The court in Wachter Management Company v. Dexter \& Chaney, Inc. ${ }^{35}$ applied the UCC to find that a software vendor could not alter the terms of a negotiated agreement with a shrinkwrap agreement. Dexter \& Chaney, Inc. ("DCI"), a software services

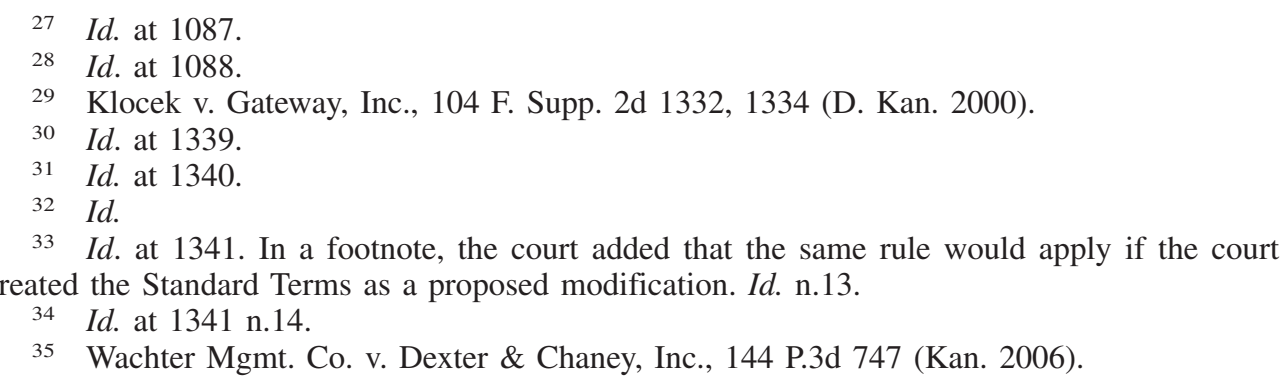


company, and Wachter, a construction management company, engaged in lengthy negotiations for the purchase of a software system. DCI issued a written proposal to Wachter which did not contain an integration clause or any language indicating that additional terms might be forthcoming. The proposal was signed by Wachter, and DCI then shipped the software. ${ }^{36}$ Enclosed with the software was a shrinkwrap agreement which contained an integration clause and a choice of law/venue provision. After having problems with the software, Wachter sued DCI for breach of contract and DCI moved to dismiss based on improper venue. ${ }^{37}$ The court found that the shrinkwrap agreement was an attempt to amend the contract under Sections 2-207 and 2-209 of the UCC and required express assent. ${ }^{38}$ Furthermore, installing and using the software, rather than returning it, was not sufficient to establish express consent to the additional or different terms. ${ }^{39}$

The foregoing cases are notable because they are in the minority of cases which have refused to enforce shrinkwrap agreements after ProCD. They relied upon an analysis under UCC $\$ 2-207$ to find the terms required express consent in order to be valid. The majority of courts, however, have followed the rationale in ProCD and found shrinkwraps to be an enforceable contracting form even under the UCC. ${ }^{40}$

The courts upholding shrinkwraps focus on another section of the UCC-Section 2-204-which permits contracts to be formed "in any manner sufficient to show agreement" even though "the moment of its making is undetermined." ${ }_{11}$ For example, in Brower v. Gateway 2000, the court agreed with the rationale in Hill and ProCD that there was no agreement upon placement of the order or receipt of the goods, but that the agreement was formed "[b]y the terms of the Agreement ... only after the consumer has affirmatively retained the merchandise for more than 30 days." 42 Similarly, the court in M.A. Mortenson Co., Inc. v. Timberline Software Corp. held that under UCC $\S 2-204$ the terms of a shrinkwrap license were enforceable and that the customer's use of the software constituted assent to the agreement. ${ }^{43}$ In Meridian Project Systems, Inc. v. Hardin Construction Co., the district court for the Eastern District of California acknowledged that the validity of shrinkwraps was "much-disputed" 44 but found "the
Id. at 749 .
Id. at 750 .
Id. at 751 .
39 Id. at 751-52. Similarly, the court in Arizona Retail Sys., Inc. v. Software Link, Inc., 831

F. Supp. 759 (D. Ariz. 1993), applied UCC Sections 2-207 and 2-209 to find that shrinkwrap terms constituted a proposal to modify the terms of an agreement.

40 There is nothing in UCC $\$ 2-207$ which states that it is inapplicable to transactions involving only one form. See, e.g., Colin P. Marks, Not What, But When Is an Offer: Rehabilitating the Rolling Contract, 46 ConN. L. REv. 73, 107 (2013) (characterizing as a "doctrinal blunder" and "blatantly wrong" Easterbrook's claim in ProCD and Hill that Section 2-207 applies only to situations involving only one form).

41 U.C.C. § 2-204.

42 Brower v. Gateway 2000, Inc., 246 A.D.2d 246, 251 (N.Y. App. Div. 1998).

43 M.A. Mortenson Co. v. Timberline Software Corp., 998 P.2d 305, 313 (Wash. 2000).

44 Meridian Project Sys., Inc. v. Hardin Const. Co., 426 F. Supp. 2d 1101, 1106 (E.D. Cal. 2006). 
Seventh Circuit's rationale in ProCD compelling." 45 It stated that the EULA ${ }^{46}$ was not invalid simply because it was received in the package containing the software. The court emphasized that the defendant had notice of the EULA and had an opportunity to return the software if the defendant did not agree to the terms of the EULA. Oddly, rather than focusing on assent and contract formation, the court concluded that the EULA was "not an unconscionable contract or a contract of adhesion" and "may be an enforceable contract." 47

The recognition of rolling contracts shook loose the common law and UCC rules of offer and acceptance, and paved the way for other nontraditional contracting forms, notably the "clickwrap" and the "browsewrap." The term clickwrap refers to digital terms that are agreed to by clicking on the word "Agree," "Accept," or something similar. ${ }^{48}$ Installing software often requires clicking acceptance to terms even if the software is also governed by the terms of a shrinkwrap license. ${ }^{49}$ The term browsewrap refers to digital terms that are accessible by clicking on a hyperlink with the words "Legal," "Terms," "Terms of Use," or similar words. ${ }^{50}$

\section{B. Clickwrap Agreements}

A clickwrap is a digital agreement that requires the user to click on an acceptance text or icon to indicate assent. Unlike a shrinkwrap, which results in a contract if the buyer fails to reject the terms, a clickwrap requires an affirmative manifestation of assent. ${ }^{51}$ Accordingly, courts have generally upheld the validity of clickwrap agreements.

45 Id. at 1107.

46 The court noted that although the EULA did not become effective upon the tearing of shrinkwrap, it was nevertheless considered a shrinkwrap license because it was contained within the packaging for the software, not on the outside of the box. Id. at 1106 n.4.

$47 \quad$ Id. at 1107.

48 Specht v. Netscape Commc'ns Corp., 306 F.3d 17, 22 n.4 (2d Cir. 2002) (referring to a clickwrap as an online software license agreement which presents users with a message that requires a manifestation of assent by clicking on an icon); Register.com, Inc. v. Verio, Inc., 356 F.3d 393, 429 (2d Cir. 2004) (describing a clickwrap license as one which presents the end user with a message that requires the user to "manifest his or her assent to the terms of the license agreement by clicking on an icon").

49 This was the case in ProCD v. Zeidenberg, where the software contained both a shrinkwrap license and a clickwrap which appeared upon installation.

50 Fteja v. Facebook, Inc., 841 F. Supp. 2d 829, 836 (S.D.N.Y. 2012) (defining a "pure-form browsewrap" as one where the website contains a notice stating that merely by using the services of a website, the user is agreeing to be bound by the site's terms of service); Sw. Airlines Co. v. Boardfirst, L.L.C., No. 06-CV-0891-B, 2007 WL 4823761, at *4 (N.D. Tex. Sept. 12, 2007) (noting that browsewraps "typically ... involve a situation where a notice on a website conditions use of the site upon compliance with certain terms or conditions, which may be included on the same page as the notice or accessible via a hyperlink"); Mark A. Lemley, Terms of Use, 91 MinN. L. REv. 459, 460 (2006) (defining a browsewrap as a situation where the user "does not see the contract at all" but the license terms provide that using the site constitutes acceptance "whether the user knows it or not").

51 As discussed in the preceding section, clickwraps may still raise the same doctrinal issues as shrinkwraps if they are "rolling clickwraps" which appear after the acts constituting the transaction have been completed. 
In an early case, Caspi v. Microsoft Network, ${ }^{52}$ a New Jersey appellate court enforced a forum selection clause in a scrollable textbox that required users to click "I agree." The court stated that the use of an electronic rather than print medium created "no significant distinction," and noted that the plaintiffs "were free to scroll through the various computer screens that presented the terms of their contracts before clicking their agreement." 53

i.LAN Systems, Inc. v. Netscout Service Level Corp. involved a clickwrap agreement that followed a negotiated agreement. The parties signed a value added reseller agreement which provided that the plaintiff, i.LAN, agreed to resell the defendant Netscout's software to customers. ${ }^{54}$ The parties had a disagreement regarding a term in a purchase order and i.LAN sued, seeking specific performance. The defendant argued that the clickwrap license agreement limited its liability to the price paid for the software.

The court noted that there were three contracts involved in the dispute: the reseller agreement, the purchase order relating to the specific transaction at issue, and the clickwrap license agreement which i.LAN agreed to when it installed the software. The clickwrap stated that it did not affect existing or subsequent written agreements or purchase orders. The court concluded that this meant that where the reseller agreement and the purchase order are silent, the clickwrap license terms would fill the void. It also ruled that even if the clickwrap permitted specific performance, the court would not award it because Netscout's software was not unique. It then discussed the limitation of liability provision in the clickwrap agreement under both UCC Section 2-204 and Section 2-207. The court stated that under Section 2-204, i.LAN manifested assent by clicking on "I agree," so the agreement was enforceable. The court stated that under Section 2-207, the crucial issue was whether i.LAN accepted the clickwrap license either explicitly by clicking "I agree" or implicitly. The court then analyzed the two leading cases dealing with rolling terms in software transactions, Step-Saver and ProCD. It noted that the analytical difference between the two cases is "whether 'money now, terms later' forms a contract (i) at the time of the purchase order or (ii) when the purchaser receives the box of software, sees the license agreement, and does not return the software." 55 In other words, if the purchase order was the contract, Section 2-207 requires explicit assent. If the contract is not formed until after the buyer has an opportunity to read the license, Section 2-204 applies and the act of keeping the software constitutes implicit assent. ${ }^{56}$ The court sided with the rationale in ProCD, and enforced the clickwrap license:

'Money now, terms later' is a practical way to form contracts, especially with purchasers of software. If ProCD was correct to enforce a shrinkwrap license agreement, where any assent is implicit, then it must also be correct to enforce a clickwrap license agreement, where the assent is explicit. To be sure, shrinkwrap and clickwrap license agreements share the defect of any standardized contract-they are susceptible to the inclusion of terms that border on the

52 Caspi v. Microsoft Network, L.L.C., 732 A.2d 528 (N.J. Super. Ct. App. Div. 1999).

$53 \quad I d$. at 532.

54 i.Lan Sys., Inc. v. Netscout Serv. Level Corp., 183 F. Supp. 2d 328, 330 (D. Mass. 2002).

55 Id. at 338.

56 Id. 
unconscionable-but that is not the issue in this case. The only issue before the Court is whether clickwrap license agreements are an appropriate way to form contracts, and the Court holds they are. In short, i.LAN explicitly accepted the clickwrap license agreement when it clicked on the box stating 'I agree.' 57

Finally, the court stated that even if Section 2-207 governed, i.LAN implicitly accepted the clickwrap license agreement because the additional terms were not material. ${ }^{58}$

Specht v. Netscape Communications Corp. furthered the development of wrap contract doctrine beyond the parameters of the UCC. Plaintiffs were individuals who had downloaded free software from Netscape Communications Corporation ("Netscape"). 59 The plaintiffs wanted to download Netscape's browser, Communicator, but first downloaded and installed SmartDownload, a software plug-in that enhanced Communicator's browsing capabilities. At or near the bottom of the page were the words "Start Download" and a tinted button labeled "Download" which, if clicked, initiated the download. Plaintiffs then installed Communicator. During the installation process, they were shown a scrollable text of the license agreement and were not allowed to complete installation until clicking on a "Yes" button to indicate acceptance. The license agreement contained a clause stating that disputes were subject to arbitration in Santa Clara County, California. ${ }^{60}$ Plaintiffs claimed that both Communicator and SmartDownload created and stored files on their computers which communicated information about their browsing history to Netscape in violation of federal laws. The defendants sought to compel arbitration according to the terms of the license agreement. ${ }^{61}$

The Second Circuit noted that there was no clickwrap presentation during the downloading process for SmartDownload. The "sole reference" to SmartDownload's license terms on the webpage containing the download was located in text that was visible only if the plaintiffs had scrolled to the bottom of the page. Furthermore, the court noted that even if a user did happen to scroll down past the download button, the terms would not have been immediately displayed as clickwrap terms. Instead, the user would have read a notice that contained a hyperlink to a list of hyperlinked agreements, including one for the Communicator products. The user would have to then click on that link to be able to view the license terms which included the arbitration clause. ${ }^{62}$

The defendants argued that because notice of the SmartDownload license terms was on the next scrollable screen, plaintiffs were on "inquiry notice" of the terms. ${ }^{63}$ The Specht court disagreed:

What plaintiffs saw when they were being invited by defendants to download this fast, free plug-in called SmartDownload was a screen containing praise for the product and, at the very bottom of the screen, a 'Download' button ... We are not persuaded that a reasonably prudent offeree in these circumstances would have known of the existence of license terms. Plaintiffs

\footnotetext{
57 Id.

58 Id.

59 Specht v. Netscape Commc'ns Corp., 306 F.3d 17, 21 (2d Cir. 2002).

60 Id. at 22.

61 Id. at 21.

62 Id. at 23 .

63 Id. at 30.
} 
were responding to an offer that did not carry an immediately visible notice of the existence of license terms or require unambiguous manifestation of assent to those terms. ${ }^{64}$

The court acknowledged that the same principles of contract assent that apply to the physical world apply to online transactions, but recognized that the analogy between the paper and digital contracting worlds was imperfect:

When products are 'free' and users are invited to download them in the absence of reasonably conspicuous notice that they are about to bind themselves to contract terms, the transactional circumstances cannot be fully analogized to those in the paper world of arm's-length bargaining.

The court distinguished ProCD and other shrinkwrap cases as they involved tangible products and printed terms and the terms were conspicuous. It also distinguished Caspi and similar cases involving online transactions because they involved active manifestations of consent, such as clicking on an "I Agree" button. ${ }^{65}$ In so doing, the Specht court established a standard for determining assent in the online contracting environment:

Reasonably conspicuous notice of the existence of contracts terms and unambiguous manifestation of assent to those terms by consumers are essential if electronic bargaining is to have integrity and credibility. We hold that a reasonably prudent offeree in plaintiffs' position would not have known or learned, prior to acting on the invitation to download, of the reference to SmartDownload's license terms hidden below the 'Download' button on the next screen. ${ }^{66}$

Specht, influential for shifting the focus away from the timing of formation and toward an inquiry regarding notice and manifestation of assent, is also notable for being an early case involving an analysis of both the clickwrap and browsewrap contracting forms.

\section{Browsewrap Agreements}

A browsewrap agreement contains terms and conditions which are indicated with a hyperlink with words such as "Terms of Use." 67 The user manifests assent simply by using the website after receiving notice of the terms. ${ }^{68}$

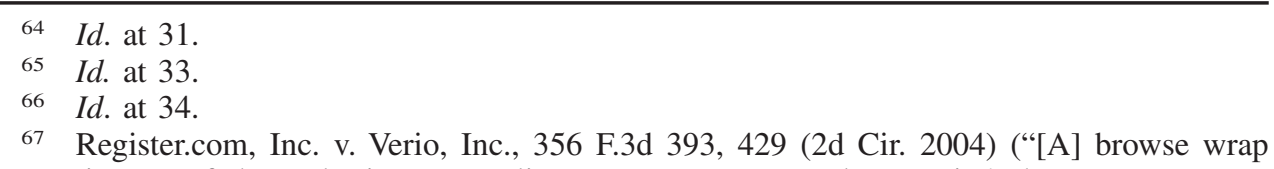
license is part of the web site [, e.g., license terms are posted on a site's home page or are accessible by a prominently displayed hyperlink,] and the user assents to the contract when the user visits the web site.") (quoting Pollstar v. Gigmania Ltd., 170 F. Supp. 2d 974, 981 (E.D. Cal. 2000)) (alterations by court).

68 See Hines v. Overstock.com, Inc., 668 F. Supp. 2d 362, 366 (E.D.N.Y. 2009) (explaining that browsewrap agreements do not require the user to manifest assent). 
In perhaps the first case addressing browsewraps, Pollstar v. Gigmania, ${ }^{69}$ the court expressed concern about the conspicuousness of a link to license terms which was not underlined and was in small gray print on gray background. ${ }^{70}$ It declined, however, to declare the browsewrap form unenforceable, citing ProCD for the proposition that "people sometimes enter into a contract by using a service without first seeing the terms."71

A more illuminating case was Register.com v. Verio. In that case, the plaintiff Register was a registrar of Internet domain names and was contractually obligated to ICANN (a non-profit organization established to administer the Internet domain name system) to permit use of registrants' contact information ("WHOIS information") "for any lawful purposes except to: ... support the transmission of mass unsolicited, commercial advertising or solicitations via email (spam) ..." ${ }^{72}$ Register's response to queries for WHOIS information contained a legend stating that by submitting the query the requester agrees that it will use the data "only for lawful purposes" and that "under no circumstances" will the requester use the data to "support the transmission of mass unsolicited, commercial advertising or solicitation via email."73 Register also offered website development services. During the registration process, Register allowed registrants to elect whether they wanted to receive marketing communications from it.

The defendant, Verio, also offered website development services and competed with Register. Verio created an automated software program which would submit multiple WHOIS queries of various registrars. Verio would then send marketing solicitations, including by email, to potential customers. Some of Verio's solicitations referred to the recipient's recent registration through Register, which led some of them to complain to Register on the assumption that Register had ignored their election not to receive solicitations. ${ }^{74}$ Register demanded that Verio cease and desist from marketing to registrants. It also changed its legend to prohibit the use of WHOIS information for mass solicitations "via direct mail, electronic mail, or by telephone"75 even though direct mail and telephone solicitations were apparently "lawful purposes" under its agreement with ICANN. Verio ceased using WHOIS information in email marketing, but refused to stop marketing by direct mail and telephone. Register sued and the trial court enjoined Verio from accessing Register.com's WHOIS database except in accordance with its terms and conditions. ${ }^{76}$ It also enjoined Verio from using data obtained from Register's computer networks for marketing purposes.

On appeal to the Second Circuit, Verio contended that it never became bound to the terms and conditions of Register's legend because it appeared only after Verio had

69 Pollstar v. Gigmania Ltd., 170 F. Supp. 2d 974 (E.D. Cal. 2000). The court noted that there were "[n]o reported cases" that had ruled on the enforceability of a browsewrap license at the time it rendered its decision. $I d$. at 981.

$70 \quad I d$. at 981.

71 Id. at 982.

72 Register.com v. Verio, 356 F.3d at 396 (quoting ICANN Registrar Accreditation Agreement) (alterations by court).

73 Id.

$74 \quad I d$. at 397.

75 Id.

$76 \quad$ Id. at 398. 
received the WHOIS data. The court rejected the argument, noting that Verio was "daily submitting numerous queries, each of which resulted in its receiving notice of the terms Register exacted." 77 Because Verio actually knew of Register's restrictions, it was subject to them.

The court distinguished the Specht case because there was "no way to determine that any downloader" in that case had seen the terms on which the software was offered. ${ }^{78}$ In the case at hand, by contrast, "Verio admitted that ... it was fully aware of the terms on which Register offered the access" to its computers. ${ }^{79}$ The court also rejected the rationale in another case, Ticketmaster Corp. v. Tickets.com, ${ }^{80}$ where the court declined to grant a preliminary injunction that would have enforced Ticketmaster's terms of use. The court in Ticketmaster noted that there was insufficient proof of agreement as the user was not required to click "I agree" before proceeding. The Register.com v. Verio court stated that there was a "crucial difference" between Specht, where there was insufficient evidence that the user had seen the terms before downloading the software, and Ticketmaster, where the defendant "knew full well the terms on which the information was offered" but did not have to click to agree. The court continued:

Under the circumstances of Ticketmaster, we see no reason why the enforceability of the offeror's terms should depend on whether the taker states (or clicks), 'I agree.'

We recognize that contract offers on the Internet often require the offeree to click on an 'I agree' icon. And no doubt, in many circumstances, such a statement of agreement by the offeree is essential to the formation of a contract. But not in all circumstances. While new commerce on the Internet has exposed courts to many new situations, it has not fundamentally changed the principles of contract. It is standard contract doctrine that when a benefit is offered subject to stated conditions, and the offeree makes a decision to take the benefit with knowledge of the terms of the offer, the taking constitutes an acceptance of the terms, which accordingly become binding on the offeree. ${ }^{81}$

Although the court in Register.com v. Verio expressly rejected the browsewrap label because there was no hyperlink to the proposed terms, ${ }^{82}$ the court's analysis was soon adopted by other courts evaluating the enforceability of online contracts, many of which did not fit neatly into the "click-" or "browse-" wrap categories.

\section{THE EVOLVING STANDARD OF NOTICE AND MANIFESTATION OF CONSENT}

The early cases approving wrap contracting forms followed Judge Easterbrook's championing of their efficiency and focused on two factors in evaluating enforceability:

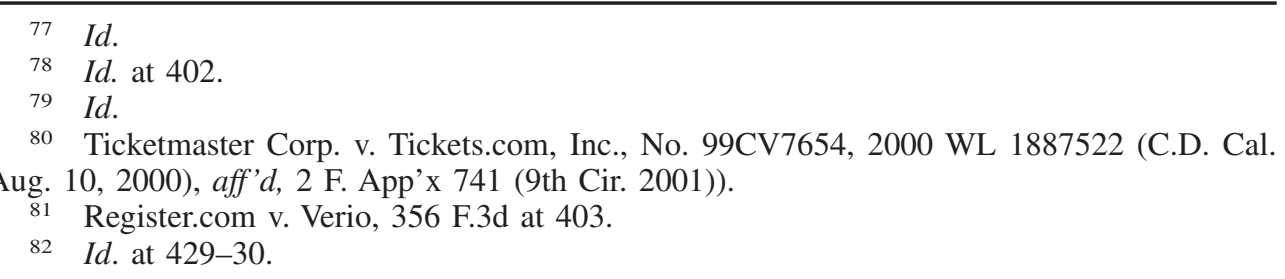




\section{Research handbook on electronic commerce law}

whether the non-drafting party had notice of terms and whether the non-drafting party had manifested assent. By contrast, under both the UCC and common law, evaluation of contract formation involving traditional paper contracts tends to center around the timing of acceptance. Notice and manifestation of assent has become the standard for evaluating wrap contracts after ProCD and Register.com. Strangely, this analysis has now become the primary one even when the online contract involves a sale of goods and should be covered by Article 2 of the UCC. ${ }^{83}$

Notice may be either constructive or actual. ${ }^{84}$ Constructive notice will be found if the notice was "reasonable." Manifestation of consent may be either active or passive, meaning that the adherent may indicate assent by doing something or by failing to act after receiving notice. Thus, a consumer may be deemed to have entered a contract if he or she either affirmatively assents to it or fails to reject it after having the opportunity to do so.

Website visitors manifest assent to clickwraps by clicking or to browsewraps by not leaving the website after receiving notice that proceeding constitutes acceptance. As a practical matter, courts conflate notice and manifestation of consent and typically view the act of clicking as evidence of both. There are some notable exceptions, however, where it was not clear that the act of clicking meant agreement to legal terms, such as in Specht. ${ }^{85}$

Notice is more difficult to prove where the user is not required to affirmatively manifest assent. It would be an oversimplification, however, to conclude that clickwraps are enforceable while browsewraps are not. Whether the user receives notice of browsewrap terms is more fraught with uncertainty as there is no action that the user must take indicating that he or she has received notice. In the few cases where courts have enforced browsewraps, the user received actual notice of terms. In Southwest Airlines v. Boardfirst, for example, the court found that notice requirements were met because the defendant Boardfirst received Southwest's cease-and-desist letter. ${ }^{86}$ In other cases, the user had engaged in bad faith activity or unfair business practices, such as copying content from another website, which he knew or should have known was

83 See, e.g., Nguyen v. Barnes \& Noble, Inc., 763 F.3d 1171, 1175-76 (9th Cir. 2014) (delving directly into whether contract was a "clickwrap" or a "browsewrap" without first discussing the UCC); In re Zappos.com, Inc., Customer Data Sec. Breach Litig., 893 F. Supp. 2d 1058, 1063 (D. Nev. 2012) (finding Zappos' Terms of Use to be a browsewrap without first discussing the UCC).

84 Sw. Airlines Co. v. BoardFirst, L.L.C., No. 3:06-CV-0891-B, 2007 WL 4823761, at *5 (N.D. Tex. Sept. 12, 2007) (stating that although the outcome in cases assessing the enforceability of browsewraps is mixed, "one general principle" that emerges is that "the validity of a browsewrap license turns on whether a website user has actual or constructive knowledge of a site's terms and conditions prior to using the site"); Cairo v. CrossMedia Servs., Inc., No. C 04-04825 JW, 2005 WL 756610 (N.D. Cal. Apr. 1, 2005).

85 Specht v. Netscape Commc'ns Corp., 306 F.3d 17, 32 (2d Cir. 2002) ("When products are 'free' and users are invited to download them in the absence of reasonably conspicuous notice that they are about to bind themselves to contract terms, the transactional circumstances cannot be fully analogized to those in the paper world of arm's-length bargaining.").

86 Sw. Airlines Co. v. BoardFirst, 2007 WL 4823761, at *7. 
prohibited by the website operator. ${ }^{87}$ Interestingly, even those courts that have invalidated browsewrap contracts have not rejected or invalidated the browsewrap as a valid contracting form. Rather, courts have focused on whether the particular browsewrap at issue in the given case was presented in a way that fulfilled the requirements of reasonable notice.

The distinction between clickwrap and browsewrap grows increasingly blurred as websites employ digital forms that incorporate elements of both contracting forms. One common multi-wrap form requires the user to click to proceed, but the click button itself does not indicate acceptance to contract terms. Instead, the click icon is placed near a hyperlink (browsewrap) that indicates that legal terms apply. While some courts have upheld multi-wrap forms, others have not. For example, in Nguyen v. Barnes \& Noble, Inc., the Ninth Circuit found that the placement of a hyperlink to the Terms of Use, which was viewable without scrolling and was less than 1 to $1 \frac{1}{2}$ inches from the button the user had to click to commence the check-out process, ${ }^{88}$ failed to provide constructive notice. ${ }^{89}$ By contrast, the federal district court in Fteja v. Facebook, Inc. ${ }^{90}$ found that a link to the Terms of Use that was placed immediately below the "Sign Up" button on Facebook's home page provided users with notice and the user manifested assent by clicking on the button. There is little distinction in the display of the multi-wrap in these two cases. In both cases, the click button does not state "Accept" but indicates some other action- "Sign Up" in the case of Facebook and "Begin Checkout," "Sign In," and "Place My Order" in the case of Barnes \& Noble. On both websites, the click button appears very close to a hyperlink to the Terms of Service. The only difference is that the Barnes \& Noble website did not indicate that clicking constituted acceptance to the Terms of Service, while on Facebook's website, text above the "Sign Up" icon states "By clicking Sign up, you agree to our Terms and that you have read our Data Policy, including our Cookie Use." The difference between the two cases is confusing because a user would be no more or less likely to click on a Terms hyperlink that was merely visible in one case and labeled as agreed to in another. The reality is that most users don't notice the Terms hyperlink regardless of the accompanying language. Most people don't bother reading website terms of use even when they are immediately visible, and they are less likely to do so when the extra effort of clicking on a hyperlink to do so is required.

87 See Lemley, supra note 50, at 470 n.37 ("Indeed, all four cases to enforce a browsewrap involved allegations of a competitor linking to or scraping data from the Web site, and included allegations of trespass to chattels and other torts as well.”). The four cases referred to by Lemley are Register.com, Inc. v. Verio, Inc., 356 F.3d 393, 393 (2d Cir. 2004); Cairo, Inc. v. Crossmedia Servs., Inc., No. C04-04825JW, 2005 WL 756610, at *1 (N.D. Cal. Apr. 1, 2005); Ticketmaster Corp. v. Tickets.com, Inc., No. CV997654HLHVBKX, 2003 WL 21406289, at*1 (C.D. Cal. Mar. 7, 2003); and Pollstar v. Gigmania, Ltd., 170 F. Supp. 2d 974, 975 (E.D. Cal. 2000).

88 Appellant's Reply Brief, Nguyen, 763 F.3d 1171 (No. 12-56628), 2013 WL 2403561, at $* 2$.

89 Nguyen, 763 F.3d at 1177-78 (noting that the "Terms of Use" link appears either directly below the relevant button a user must click to checkout or just a few inches away but that "the hyperlink alone is not enough to give rise to constructive notice").

90 Fteja v. Facebook, Inc., 841 F. Supp. 2d 829, 837 (S.D.N.Y. 2012). 
The click-browsewrap hybrid is not the only type of multi-wrap. There is also the rolling clickwrap form, which combines the "pay-now-terms-later" form of shrinkwraps but presents the terms in a clickwrap or click-browsewrap form. For example, in Tompkins v. 23andme, ${ }^{91}$ the transaction involved a two-step process by which customers purchased a DNA testing kit and then, at a later date, registered and created an account in order to submit saliva samples for DNA analysis. The purchase portion of the transaction was subject to a browsewrap - a hyperlink to the Terms of Service-and the registration and creation of the account was subject to a click-browsewrap hybrid.

Multi-wrap contracts tend to confuse courts. In Fteja v. Facebook, the court stated that the "Terms of Use were not exactly a true browsewrap" although they were "not a pure-form clickwrap agreement, either." 92 After some discussion, the court concluded:

Facebook's Terms of Use are somewhat like a browsewrap agreement in that the terms are only visible via a hyperlink, but also somewhat like a clickwrap agreement in that the user must do something else — click 'Sign Up' - to assent to the hyperlinked terms. Yet, unlike some clickwrap agreements, the user can click to assent whether or not the user has been presented with the terms. ${ }^{93}$

The precedent set by Fteja, in turn, provided the Tompkins v. 23andme court with support to conclude that "[t]he fact that the TOS were hyperlinked and not presented on the same screen does not mean that customers lacked adequate notice." 94 Using Fteja to settle the issue of the validity of the contracting form, the Tompkins v. 23andme court failed to acknowledge the rolling nature of the Terms of Service. Plaintiffs had argued that the Terms of Use resembled a shrinkwrap agreement because they were presented to the customer only after paying for the product. ${ }^{95}$ The court disagreed, stating that the customer accepted the terms by clicking, not by failing to return the product. ${ }^{96}$ The form in which the terms are presented, however, does not make it any less of a rolling contract. The precedent established by ProCD v. Zeidenberg and Hill v. Gateway required that, in order for a rolling contract to be enforceable, customers must be presented with an opportunity to reject terms and receive a refund. ${ }^{97}$ Customers of 23andme, however, were not given that opportunity. Customers could cancel the purchase of the DNA testing kits only within sixty minutes of the sale. ${ }^{98}$ They could obtain partial refunds (approximately sixty-five percent of the purchase price of the

\footnotetext{
91 Tompkins v. 23andMe, Inc., No. 5:13-CV-05682-LHK, 2014 WL 2903752, at *2-3 (N.D. Cal. June 25, 2014).

92 Fteja v. Facebook, Inc., 841 F. Supp. 2d 829, 837 (S.D.N.Y. 2012).

93 Id. at 838.

94 Tompkins, $2014 \mathrm{WL} 2903752$, at $* 8$.

95 Id. at $* 7$.

$96 \quad I d$. at $* 8$.

97 See Marks, supra note 40, at 100 (noting that a "consistent theme in rolling contract cases is the right of the buyer to return the goods should the buyer not agree to the terms presented").
}

98 Tompkins, $2014 \mathrm{WL} 2903752$, at $* 7-8$. 
kits) but only if the refund request was made within thirty days of purchase. ${ }^{99}$ The customer could not receive any refund if the request was made more than thirty days after purchase or if the laboratory had already received the DNA sample. ${ }^{100}$ Yet, the customer could submit a DNA sample and create an account up to twelve months from the date of purchase. ${ }^{101}$ A customer could then be presented with the terms, reject them, and have no opportunity to receive a full refund. If the customer registered more than thirty days after purchase, he would receive no refund at all. The court ignored the practical inability of the consumer to reject terms and instead fixated on the act of clicking, stating, "Plaintiffs' argument that 23andMe's refund policy was too restrictive does not negate their affirmative assent to the TOS."102 The 23andMe decision illustrates just how much wrap contract cases deviate from traditional contract law, and even from early wrap contract cases such as ProCD and Specht.

Yet, other courts appear to be pulling back from the divergent stream of wrap contract law and applying mainstream contract law principles to wrap contracts. In Schnabel v. Trilegiant Corp., ${ }^{103}$ for example, the Second Circuit, applying California law, found that the terms presented via hyperlink in a later email were not part of any contract between the parties. The plaintiffs were consumers who had made purchases on a website and then, upon seeing a "Cash Back" notice, enrolled in a discount subscription service with another merchant. Plaintiffs claimed that they were enrolled in the discount program without their knowledge when they clicked "Yes" to receive the cashback award. ${ }^{104}$ They later received a welcome email which contained information about the discount program's terms and conditions. The court found that if a contract had been formed, it would not have included the terms in the email as any contract would have already been formed. ${ }^{105}$

In Knutson v. Sirius XM Radio, ${ }^{106}$ the Ninth Circuit, also applying California law, found that a consumer did not consent to the terms of a customer agreement which required the consumer to actively reject terms. In that case, the plaintiff Knutson purchased a Toyota which included a free trial subscription to Sirius XM satellite radio. ${ }^{107}$ About a month after the subscription was activated, he received a "Welcome Kit" from Sirius XM which contained a Customer Agreement. ${ }^{108}$ The Customer Agreement set out the terms and conditions of use during the ninety-day trial period. ${ }^{109}$

99 The testing kits cost $\$ 99$ each. The company charged $\$ 25$ for each returned kit and shipping and handling. Id. 23andme's website states that shipping and handling is typically \$9.95. 23andMe Shipping Rates and Information, 23ANDME, https://customercare.23andme.com/ hc/en-us/articles/202907920-Shipping-rates-and-information.

100 Tompkins, 2014 WL 2903752, at *8.

101 23andMe Refund and Replacement Policy, 23ANDME, https://customercare.23andme. com/hc/en-us/articles/202907780-23andMe-Refund-and-Replacement-Policy.

102 Tompkins, 2014 WL 2903752, at *8.

103 Schnabel v. Trilegiant Corp., 697 F.3d 110 (2d Cir. 2012).

104 Id. at $114-15$.

105 Id. at 122.

106 Knutson v. Sirius XM Radio Inc., 771 F.3d 559 (9th Cir. 2014).

107 Id. at 561-62.

108 Id. at 562.

109 Id. 
It further stated that by "accessing or using the site or the service" the consumer agreed to be bound by the terms, and that if the consumer wished to reject the terms he had to notify the company "immediately." 110 Furthermore, it stated that if the consumer did not cancel the subscription within " 3 business days" of activation, it meant that the consumer agreed to the terms. ${ }^{111}$ The court disagreed. It noted that Sirius XM's offer was not "clearly and effectively communicated" to Knutson and that Knutson "could not be obligated to act where there was no effective notice that action was required." 112 The court concluded that Knutson's continued use of the service did not constitute assent to the provisions of the Customer Agreement. ${ }^{113}$ Although the Customer Agreement was not an online contract, its rolling nature, and the fact that using the site or services was deemed to constitute acceptance, should influence how courts decide future online contracting cases.

Another case, Berkson v. Gogo LLC, ${ }^{114}$ recognized the importance of website design and presentation of terms and may be a harbinger of a course correction for wrap contract doctrine. The class action plaintiffs in Berkson were airline passengers who had signed up to use the defendants' 115 in-flight wi-fi service. They alleged that the defendants misled them into believing they were purchasing only a one-month subscription but instead charged their credit cards on a monthly basis without adequate notice or consent. The defendants argued that the plaintiffs consented to the automatic renewal and the mandatory arbitration and venue clauses. ${ }^{116}$ The defendants' motion sought to transfer venue and compel arbitration. The court found that one of the primary policy issues raised by the case was the issue of how courts should deal with wrap contracts and stated:

In the absence of contrary proof, it can be assumed that the burden should be on the offeror to impress upon the offeree-i.e., the average internet user-the importance of the details of the binding contract being entered into. The burden should include the duty to explain the relevance of the critical terms governing the offeree's substantive rights contained in the contract. ${ }^{117}$

In a long and careful opinion, Judge Jack Weinstein of the federal district court for the Eastern District of New York provided a promising indication that there may be a shift in the judicial treatment of wrap contracts. ${ }^{118}$ First, the court stated that the "starting point of analysis must be the method through which an electronic contract of adhesion is formed. The inquiry does not begin, as defendants argue, with the content of the provisions themselves." 119 Judge Weinstein described four general categories of online

\footnotetext{
$110 I d$.

111 Id.

$112 \quad I d$. at 566.

113 Id.

114 Berkson v. Gogo LLC, 97 F. Supp. 3d 359 (E.D.N.Y. 2015).

115 The defendants were Gogo, LLC and its parent corporation, Gogo., Inc. Id. at 365.

$116 I d$.

117 Id. at 382.

118 In the interests of full disclosure, the court also cites this author's book, WRAP CONTRACTS, cited supra note 1, throughout the opinion.

119 Id. at 383.
} 
consumer contracts: browsewraps, clickwraps, scrollwraps, and sign-in-wraps. ${ }^{120}$ Browsewraps require only a passive acceptance where a user assents merely by using the website. ${ }^{121}$ Clickwraps require a user to click an "I agree" icon which is next to a hyperlink containing "terms of use." 122 Scrollwraps, on the other hand, make at least some terms immediately visible but require users to scroll through the terms to read all of them. ${ }^{123} \mathrm{He}$ noted that some courts used the term "clickwrap" when they were dealing with "scrollwrap" which gives the consumer a "realistic opportunity to review and scroll through the electronic agreement." 124 A sign-in wrap, which the court referred to as a "questionable form of internet contracting," does not require a user to click on a box indicating acceptance to terms of use. Instead, the website is designed so that the user must sign in or register and the terms are visible during the sign-in or registration process. ${ }^{125}$

The court then gleaned several general principles from other cases concerning the validity and enforceability of Internet agreements and developed a "four-part inquiry in analyzing sign-in wraps, and electronic contracts of adhesion generally":

(1) Aside from clicking ... is there substantial evidence from the website that the user was aware that she was binding herself to more than an offer of services or goods in exchange for money? If not, the 'terms of use,' such as those dealing with venue and arbitration should not be enforced against the purchaser.

(2) Did the design and content of the website ... make the 'terms of use' ... readily and obviously available to the user? If not, the 'terms of use,' such as those dealing with venue and arbitration, should not be enforced against the purchaser.

(3) Was the importance of the details of the contract obscured or minimized by the physical manifestation of assent expected of a consumer seeking to purchase or subscribe to a service or product? If yes, then the 'terms of use,' such as those dealing with venue and arbitration, should not be enforced against the purchaser.

(4) Did the merchant clearly draw the consumer's attention to material terms that would alter what a reasonable consumer would understand to be her default rights when initiating an online consumer transaction from the consumer's state of residence ... If not, then [those material terms] should not be enforced against the consumer. ${ }^{126}$

The two plaintiffs encountered different types of wrap forms. Plaintiff Welsh was presented with a clickwrap when he created an account. ${ }^{127} \mathrm{He}$ was required to fill in all the fields marked with an asterisk. The box next to the words "I agree to the Terms of

\footnotetext{
$120 \quad$ Id. at 394.

121 Id. at 395.

122 Id. at 397.

123 Id. at 398.

$124 I d$.

$125 I d$. at 399. I refer to this type of wrap contract as a "multi-wrap" because it combines aspects of clickwraps and browsewraps. See KIM, supra note 1, at 63.

126 Berkson v. Gogo, 97 F. Supp. 3d at 402.

127 Id. at 403.
} 
Use" was not marked by an asterisk. The parties contested whether Welsh's assent was required but the court decided that "[i]t can be inferred that Welsh never clicked on this box." 128

The other plaintiff, Berkson, was presented with a sign-in wrap where one "SIGN IN" button was placed in the upper right hand corner of the page and another toward the bottom of the page. Above the SIGN IN button at the bottom of the page were the words, "By clicking 'Sign in' I agree to the terms of use and privacy policy." 29 The court noted that clicking the "SIGN IN" button did not display the hyperlinked terms. It also acknowledged that the sign-in wrap "closely resembles" the one in Fteja v. Facebook and criticized that court's reasoning:

But Fteja, and lower court cases that follow its lead, mischaracterize important Supreme Court and Court of Appeals precedent regarding contracts and the reasonable person standard that must be applied to inquiry notice of, and manifestation of assent to, the terms in a contract of adhesion. ${ }^{130}$

The court concluded that, without more, neither plaintiff could be considered to have "knowingly bound" himself to Gogo's terms. ${ }^{131}$

As these recent cases demonstrate, the law of wrap contracts continues to evolve. As online access shifts from the computer screen to the mobile screen and other devices, contracting forms will also adapt. As in the past, what constitutes "notice" and "manifestation of assent" will depend upon the context—and the court.

\section{CONTRACT LAW ADAPTATIONS}

Some courts presiding over wrap contract cases have downplayed or dismissed the differences between digital and paper forms of contracting and the differences between the online and physical world contracting environments. They have ignored that the weightlessness of digital terms might encourage their overuse as digital terms do not create cost or storage problems. Their flexible form encourages hyperlinking, thus incorporating by reference terms on other web pages which increases the burden on the consumer to find them. The absence of a signature requirement and intangibility reduces consumer awareness and increases consumer habituation to online contracting, which in turn further diminishes consumer awareness. Some courts also ignored that digital contracting forms lack the signaling effects of signed paper contracts. ${ }^{132}$ Instead, they emphasized the similarities between digital and paper terms in an effort to encourage innovation and facilitate transactions. Rather than determining whether the

\footnotetext{
$128 \quad I d$. at 370.

129 Id. at 374.

130 Id. at 403 .

131 Id. at 405 .

132 I have discussed the differences between digital contracts and paper contracts at length in other work. See Nancy S. Kim, The Wrap Contract Morass, 44 Sw. L. REV. 309 (2014); KIM, supra note 1; Nancy S. Kim, Situational Duress and the Aberrance of Electronic Contracts, 89 CHI-KeNT L. REV. 265 (2014).
} 
user actually agreed to terms, these courts focused on "constructive assent," and whether notice of terms was "reasonable." The determination of reasonableness, however, is an ex-post analysis which fails to reflect the presentation of contract terms from the standpoint of the consumer. Studies and cases support the conclusion that in online transactions consumers do not believe they have consented to contract terms and are often unaware that they have entered into a legally binding agreement. ${ }^{133}$

Contract law has mechanisms in place to address the burdens that new contracting forms place upon consumers who, quite reasonably, ignore online terms. Courts, however, have been reluctant to engage these doctrines. For example, Section 211(3) of the Restatement of Contracts, also referred to as the reasonable expectations doctrine, states that where the drafter "had reason to believe" that the party manifesting assent "would not do so if he knew that the writing contained a particular term, the term is not part of the agreement." ${ }^{134}$ As Wayne Barnes notes, Section 211(3) "qualifies the duty to read so as to prevent the merchant from unduly exploiting the consumer's failure to actually read."'135 Unfortunately, the subsection has not been applied much to contracts other than insurance contracts. ${ }^{136}$

Another underutilized doctrine-the duty of good faith and fair dealing in the performance of contracts - could be used to prevent drafting parties from enforcing certain provisions that would frustrate the reasonable expectations of the adhering party. It could, for example, be used to prevent companies from barring users from accessing their accounts without due process or from engaging in intrusive behaviors such as email scanning. It could also be used to prevent companies from modifying their services in ways that alter the bargain for customers, such as by diminishing privacy rights or making it difficult for users to discontinue a service or return a purchase without penalties or fees.

133 See, e.g., Yannis Bakos et al., Does Anyone Read the Fine Print? Consumer Attention to Standard-Form Contracts, 43 J. LEGAL STUD. 1 (2014) (finding that only one or two out of every thousand retail software shoppers access license agreements of online software companies). An experiment conducted by a group of security researchers with the backing of Europol, the European law enforcement agency, found that six people agreed to assign their first born child for the "duration of eternity" for the right to connect to a wi-fi hotspot. Tom Fox-Brewster, Londoners Give Up Eldest Children in Public Wi-Fi Security Horror Show, GuARDIAN (Sept. 29, 2014), http://www.theguardian.com/technology/2014/sep/29/londoners-wi-fi-security-herodclause. See also OMri Ben-Shahar \& CARl E. Schneider, More Than You Wanted to KNow: The FAILuRE of MANDATED Disclosure (2014) (exploring how disclosure regimes fail because consumers fail to read disclosures).

134 Restatement (SECOND) Of Contracts § 211(3). See also Wayne R. Barnes, Toward a Fairer Model of Consumer Assent to Standard Form Contracts: In Defense of Restatement Subsection 211(3), 82 WASH. L. REv. 227, 231 (2007) (arguing that Section 211(3) "provides a rule that is consistent with the objective theory of contracts and with general principles of the assent-based nature of contracts."). Barnes makes a compelling argument that Section 211 (3) is a "meaningful tool" that should be used to resolve the "cognitive dissonance" between negotiated consent and the reality of the no-reading problem). Id. at 264-74.

135 Barnes, supra note 134, at 268.

136 See id. at 231 (noting that Section 211(3) is "[o]verlooked and underappreciated"). 


\section{Research handbook on electronic commerce law}

Here are some additional ways that existing doctrinal tools could be adapted to accommodate wrap contracting realities while encouraging responsible and fair contracting practices: ${ }^{137}$

- Broader Application of the Duty of Good Faith and Fair Dealing. As noted above, contract law recognizes a duty of good faith and fair dealing in the performance of contracts. I propose that with adhesive contracts (both paper and digital), drafters should be subject to the duty to draft and present terms in good faith and in accordance with standards of fair dealing, meaning they should draft terms in such a way that they would not undermine the reasonable expectations of the adhering party. Given the contracting realities discussed above, such a standard would discourage companies from taking unfair advantage of consumers while preserving the efficiencies of standard form contracting.

- The Duty to Draft Reasonably. Courts often expect consumers to read contracts even when the terms are difficult to locate and understand. A duty to read unfairly burdens the consumer unless there is also a counterbalancing duty to draft reasonably which is imposed upon drafters. A duty to draft reasonably would require drafters to prove that they have presented the terms in a manner that encourages most people to read the terms, rather than just to click to proceed on the website. They can prove this by testing out the presentation of their terms with a focus or test group of consumers.

- A More Robust Unconscionability Doctrine. Non-negotiated terms in adhesive contracts should be presumed unconscionable except in two situations: where the terms are expressly permitted by legislation or by a regulatory agency, or where the company can prove that alternative terms were available, either on its own site or on a competitor's site, thus rebutting the presumption that the consumer lacked a meaningful choice. If offered by the drafter, the consumer-friendly terms should be the default with the consumer having the ability to opt for a less-favorable term in order to receive a discount or other benefit.

- Specific Assent. Drafters should be required to seek specific assent to terms that require a promise from the adherent or require the adherent to relinquish a right. A mandatory arbitration clause would require specific assent since it seeks to prevent the consumer from enforcing a right he or she would otherwise have. A limited license granted by the drafting party to use its services would not require specific assent by the user since in the absence of such a license, the consumer would have no right to use the services. A perpetual license to distribute and use content posted by the user and granted to the website would require specific assent as it grants rights to the website that it would not otherwise have. Adherence to codes of conduct typically would not require specific assent, although rights granted to the website to a user's personal information would require specific assent by the user.

137 Many of these proposals are discussed in more detail in KIM, supra note 1, at 174-210. 
- Duress. In some cases, a consumer's assent to a contract could be avoided by claiming duress. ${ }^{138}$ Duress is typically defined as an improper threat that left the party seeking avoidance with no reasonable alternative but to enter into the contract. ${ }^{139}$ Where a consumer has a vested interest in a product or service, and a company seeks to block consumer access to that product or service unless the consumer signs an agreement, the company's actions could be viewed as an improper threat. For example, in Tompkins v. 23andme, the company's use of an online agreement to block the consumer's access to a service for which that consumer had already paid could be considered an improper threat that left the consumer no reasonable alternative but to accept the terms.

As a practical matter, the proposed contract defenses to enforcement (unconscionability and the duty of good faith and fair dealing) may have limited applicability. Many consumer contracts contain mandatory arbitration clauses, often coupled with class action waivers. Arbitration yields no public record and thus provides no useful precedent. Furthermore, agreements which contain prohibitions on class action arbitration likely mean that few (if any) consumers will actually bring a claim given the small amounts at stake in individual consumer claims. ${ }^{140}$ Consequently, the doctrinal adjustments which strengthen the assent requirement and make a finding of contract formation more difficult—specific assent, duress, and a duty to draft reasonably—may be more effective at preventing wrap contracting abuses.

\section{CONCLUSION}

Sanctioned by courts as acceptable contracting forms, businesses exploited wrap contracts to maximum advantage. Given the unique form of wrap contracts and the online environment, judicially constructed notions of assent impose standards of behavior that place heavy burdens upon consumers. Contract law doctrines such as the duty to read, incorporation by reference, and blanket assent fail to account for the uniqueness of online contracting where weightless terms, hyperlinks, and a distracting environment affect both consumer perceptions and drafting company behavior. Not surprisingly, wrap contracts continue to spread, resulting in consumer apathy through habituation and encouraging companies' appropriation of rights through stealth terms. Courts have taken liberties with traditional contract law in order to accommodate marketplace changes but some have done so in a way that ignores how the contracting

138 I discuss situational duress more fully in another article: Kim, Situational Duress and the Aberrance of Electronic Contracts, supra note 132.

139 RESTATEMENT (SECOND) OF CONTRACTS $§ 175$ ("If a party's manifestation of assent is induced by an improper threat by the other party that leaves the victim no reasonable alternative, the contract is voidable by the victim.").

140 See Andermann v. Sprint Spectrum L.P., 785 F.3d 1157, 1160 (7th Cir. 2015) ("But doubtless [the defendant] wants arbitration because the arbitration clause disallows class action arbitration. If the Andermanns' claims have to be arbitrated all by themselves, they probably won't be brought at all, because the Andermanns if they prevail will be entitled only to modest statutory damages."'). 
environment has changed. The problems created by online contracts could be greatly diminished by adapting contract law in a way that recognizes how changes in the contracting environment have affected the behavior of both drafters and adherents. 